Article

\title{
Environmental Surveillance through Next-Generation Sequencing to Unveil the Diversity of Human Enteroviruses beyond the Reported Clinical Cases
}

\author{
Andrés Lizasoain ${ }^{1}$ (D), Daiana Mir ${ }^{2}$, Gisella Masachessi ${ }^{3}$, Adrián Farías ${ }^{3}$, Nélida Rodríguez-Osorio ${ }^{2}$, \\ Matías Victoria ${ }^{1}$, Silvia Nates ${ }^{3}$ and Rodney Colina ${ }^{1, *}$
}

1 Laboratorio de Virología Molecular, Departamento de Ciencias Biológicas, Centro Universitario Regional del Litoral Norte, Universidad de la República, Salto 50000, Uruguay; andres.lizasoain.cuelho@gmail.com (A.L.); matvicmon@yahoo.com (M.V.)

2 Unidad de Genómica y Bioinformática, Departamento de Ciencias Biológicas, Centro Universitario Regional del Litoral Norte, Universidad de la República, Salto 50000, Uruguay; dmir@unorte.edu.uy (D.M.); nelida.rodriguez@unorte.edu.uy (N.R.-O.)

3 Laboratorio de Gastroenteritis Virales y Sarampión, Instituto de Virología Dr. J. M. Vanella, Facultad de Ciencias Médicas, Universidad Nacional de Córdoba, Córdoba 5000, Argentina; gmasachessi@fcm.unc.edu.ar (G.M.); adrianalefarias@hotmail.com (A.F.); snates@fcm.unc.edu.ar (S.N.)

* Correspondence: rodneycolina1@gmail.com; Tel.: +598-473-42925

check for updates

Citation: Lizasoain, A.; Mir, D.;

Masachessi, G.; Farías, A.;

Rodríguez-Osorio, N.; Victoria, M.; Nates, S.; Colina, R. Environmental Surveillance through

Next-Generation Sequencing to Unveil the Diversity of Human Enteroviruses beyond the Reported Clinical Cases. Viruses 2021, 13, 120 https://doi.org/10.3390/v13010120

Academic Editors: Javier Martin and Erwin Duizer

Received: 19 December 2020

Accepted: 15 January 2021

Published: 17 January 2021

Publisher's Note: MDPI stays neutral with regard to jurisdictional clai$\mathrm{ms}$ in published maps and institutional affiliations.

Copyright: (C) 2021 by the authors. Licensee MDPI, Basel, Switzerland. This article is an open access article distributed under the terms and conditions of the Creative Commons Attribution (CC BY) license (https:// creativecommons.org/licenses/by/ $4.0 /)$.
Abstract: The knowledge about circulation of Human Enteroviruses (EVs) obtained through medical diagnosis in Argentina is scarce. Wastewater samples monthly collected in Córdoba, Argentina during 2011-2012, and then in 2017-2018 were retrospectively studied to assess the diversity of EVs in the community. Partial VP1 gene was amplified by PCR from wastewater concentrates, and amplicons were subject of next-generation sequencing and genetic analyses. There were $41 \mathrm{EVs}$ detected, from which $\sim 50 \%$ had not been previously reported in Argentina. Most of the characterized EVs $(60 \%)$ were detected at both sampling periods, with similar values of intratype nucleotide diversity. Exceptions were enterovirus A71, coxsackievirus B4, echovirus 14, and echovirus 30, which diversified in 2017-2018. There was a predominance of types from EV-C in 2017-2018, evidencing a common circulation of these types throughout the year in the community. Interestingly, high genetic similarity was evidenced among environmental strains of echovirus 30 circulating in 2011-2012 and co-temporal isolates obtained from patients suffering aseptic meningitis in different locations of Argentina. This study provides an updated insight about EVs circulating in an important region of South America, and suggests a valuable role of wastewater-based epidemiology in predicting outbreaks before the onset of cases in the community.

Keywords: enterovirus; poliovirus; echovirus; coxsackievirus; surveillance; wastewater-based epidemiology; aseptic meningitis; outbreak; phylogenetic analysis; next-generation sequencing

\section{Introduction}

Human Enteroviruses (EVs) comprise several viral types belonging to classical groups' coxsackievirus (CV) A and B, echovirus (E), numbered enterovirus (EV) and poliovirus (PV). Additionally, EVs are classified into four viral species (EV-A-EV-D) inside the genus Enterovirus of the family Picornaviridae [1].

Frequently, infections are mild or asymptomatic [2], but a small fraction of them lead to diseases such as aseptic meningitis (AM), encephalitis, acute hemorrhagic conjunctivitis (AHC), hand-foot-and-mouth disease (HFMD), or acute flaccid paralysis (AFP), among others $[3,4]$. The primary mode of EVs transmission remains the fecal-oral route. However, respiratory aerosols, contact with objects or surfaces contaminated with virions, as well as consumption of contaminated water also raise the risk of infection [5,6]. Infections by EVs are ubiquitous among populations; and since the primary replication site for these viruses 
is the digestive tract, large amounts of viral particles are excreted in feces during either symptomatic or asymptomatic infections [7]. Consequently, when suitable methods are employed, the study of wastewater samples allows unveiling of the diversity of EVs in the population that surrounds the sampling points [8,9].

South America has been identified as being among the regions of the world with less available information about the genetic diversity of its circulating EVs strains [10]. In particular, Argentina has extensively studied the molecular epidemiology of echovirus 30, a member of EV-B related with AM [11-13]. Additionally, there are some reports regarding outbreaks of different diseases caused by EVs [14-17]. Previous wastewater-based epidemiology studies have provided valuable information about EVs types circulating in Argentina [18-21], thus complementing clinical analysis of samples from patients with diseases associated with EVs reported in the 1990s and early 2000s [22,23]. Most of these environmental studies were carried out in the Province of Córdoba, but they were biased towards poliovirus isolation and viral strains characterization [19] or were based on Sanger sequencing of a PCR product obtained directly from the wastewater specimens [20,21]. Considering that wastewater is a complex sample in which there normally occurs a mixture of several EVs types as a result of multiple excretion events in the population [24,25], and due to the inherent diversity of types when EVs are assessed, these approaches had limitations for providing a wide understanding on the diversity of circulating EVs. Beyond all efforts for characterizing EVs' presence in Argentina, the knowledge about the circulation of more than 100 types of these viruses in the country is scarce.

In recent years, different studies have employed next-generation sequencing techniques to describe diversity, seasonality, and/or to find particular emerging types of EVs in environmental samples, achieving an in-depth view of the real diversity enclosed by each sample [25-28].

The present wastewater-based epidemiology study constitutes a great contribution to the knowledge about the circulation of EVs in Argentina and provides evidence about the usefulness of the applied methodological approach for anticipating possible outbreaks.

\section{Materials and Methods}

\subsection{Samples}

Viral concentrates $(15 \mathrm{~mL})$-which were obtained as previously described [29] by a precipitation method with polyethylene glycol (PEG) from wastewater samples (1500 mL each)-were retrospectively studied. Samples were monthly collected from the inlet of Bajo Grande wastewater treatment plant (WTP) from Córdoba City in two periods; the first period took place from January 2011 until December 2012, and the second period took place from March 2017 until February 2018. Córdoba city is the capital of the province of Córdoba, located in the central region of Argentina, and is the second most populated city of the country with approximately 1,329,604 inhabitants and a population density of 5,978 people per square mile [30]. The Bajo Grande WTP represents the sewage discharges from about $61 \%$ of the population and this facility does not treat industrial wastewater.

\subsection{Human Enteroviruses Detection and Sequencing}

Viral genomes were extracted from $140 \mu \mathrm{L}$ of viral concentrate using the QIAamp ${ }^{\circledR} \mathrm{Vi}$ ral RNA Mini Kit (Qiagen ${ }^{\mathrm{TM}}$, Hilden, Germany) according to manufacturer's instructions. A RT-nested PCR method [31] was used to amplify a partial segment of VP1-coding segment (2602-2977 positions in the genome of PV1 Mahoney strain. GenBank accession number J02281), with primers AN32-AN35 in the reverse transcription (Revert Aid RT Thermo Scientific $^{\mathrm{TM}}$, Carlsbad, CA, USA) and primers 222/224 (with Ranger DNA Polymerase Master Mix, Meridian Bioscience ${ }^{\mathrm{TM}}$, Cincinnati, OH, USA) and AN88/AN89 (with Platinum $^{\mathrm{TM}}$ SuperFi ${ }^{\mathrm{TM}}$ Taq DNA Polymerase, Invitrogen ${ }^{\mathrm{TM}}$, Carlsbad, CA, USA), in first and second PCR rounds, respectively. At the second round, AN88 and AN89 primers [31] were modified by addition of Illumina Universal Adapter sequences at the $5^{\prime}$ ends, according to the protocol of library preparation for metagenomic sequencing in Illumina MiSeq platform 
(Illumina Inc., San Diego, CA, USA) [32]. Macrogen Inc. Next Generation Sequencing Service (Seoul, Republic of Korea) prepared sequencing libraries. Samples were sequenced on Illumina MiSeq $2 \times 300 \mathrm{bp}$, producing paired end reads. Libraries from 2011-2012 and 2017-2018 were sequenced in two independent runs.

\subsection{Bioinformatics Pipeline}

Raw Illumina reads were paired using merge pairs algorithm with a minimum overlap length of $50 \mathrm{bp}$ in VSEARCH v2.11 [33]. The resulting contigs were filtered out if their lengths were $<100 \mathrm{bp}$, and if they contained homopolymer tracks $>8 \mathrm{bp}$ in length. Quality trimming of reads was performed by using -fastq_filter command and contigs with more than 1.0 total expected errors (-fastq_maxee 1.0) were discarded. In order to save time in further analyses, a dereplication step was performed using VSEARCH -derep fulllength algorithm on the processed contigs to find unique sequences by clustering at $100 \%$ sequence identity. Singletons (sequences that appear only once in the sample) and chimeras (abskew $=2$ ) were removed.

Clusters of contigs were generated with VSEARCH using identity criterion of $97 \%$, adopting a representative sequence (centroid sequence) of each cluster for further analyses. Finally, centroids sequences were mapped by VSEARCH's -usearch_global at $80 \%$ sequence identity against a Customized Human Enteroviruses Database (CHED), composed of 30,850 sequences of the viral capsid VP1 protein-coding region downloaded from NCBI nucleotide database (CHED available upon requested).

\subsection{Phylogenetic Analyses and Genetic Diversity}

A subset from CHED was generated by removing closely related sequences within each EV type. To do this, sequences were grouped by similarity (97\%) with the CD-HIT-EST tool [34] and only one sequence per cluster was selected.

An alignment for each EV species was constructed including the CHED representative sequences and centroid sequences from this study. A maximum likelihood (ML) phylogenetic tree was inferred for the completed data set of each EV species by using FastTree v2.1 software [35] with the GTR nucleotide substitution model. Lengths were rescaled to optimize the Gamma20 likelihood after using the CAT approximation to optimize the trees. The reliability of the phylogenies was estimated with the approximate likelihood-ratio test (aLRT) based on a Shimodaira-Hasegawa-like procedure [36,37]. Phylogenetic trees were visualized with FigTree v1.4.3.

Additionally, nucleotide identities values were calculated in BioEdit software v7.2.5 [38] for each pair of centroid sequences exclusively for each one of the types detected in both periods (2011-2012 and 2017-2018).

\subsection{Backgrounds of Human Enteroviruses Detection in Argentina. Link between Environmental and Clinical Isolates}

A bibliographic and nucleotide database search was conducted in order to know the most recent report in Argentina-either for environmental or clinical isolates—of each EV detected in this study.

Additionally, nucleotide sequences of clinical isolates-which were obtained from AM cases reported in different locations of Argentina between 1998 and 2012 [13] —were retrieved from GenBank nucleotide database for a genetic comparison with strains detected in wastewater by this study. Comparisons were performed through a matrix of nucleotide identity constructed in BioEdit software v7.2.5 [38]. GenBank accession numbers and information regarding location and year of detection for clinical isolates used in this analysis are available in Table S1. 


\section{Results}

3.1. Taxonomic Allocation and Distribution of Human Enteroviruses Species' Frequency and Abundance

Number of merged reads (contigs) per sample ranged between 63,293 and 118,027 (average 106,328 \pm 11,680) for 2011-2012 and between 132,716 and 300,971 (average $179,030 \pm 46,968)$ for 2017-2018. The average loss of contigs after the two-filter process for $2011-2012$ and $2017-2018$ was $14 \% \pm 4.1 \%$ and $15 \% \pm 5.3 \%$, respectively.

When considering all samples, it was observed that more than $97 \%$ of the total filtered contigs mapped to EVs sequences. At the 2011-2012 and the 2017-2018 sampling periods, on average 7 and 11 different EVs types per sample were detected, respectively (Table 1).

Throughout both sampling periods, EV-B was the most frequent and abundant detected species, while EV-C was detected in all the samples (like EV-B) during 2017-2018, with increased abundance compared to 2011-2012. EV-A was detected in a low abundance throughout the entire sampling period; with the exception of March through June 2011, when EV-A abundance was relatively higher compared to the one from the remaining months of the sampling (Figure 1).

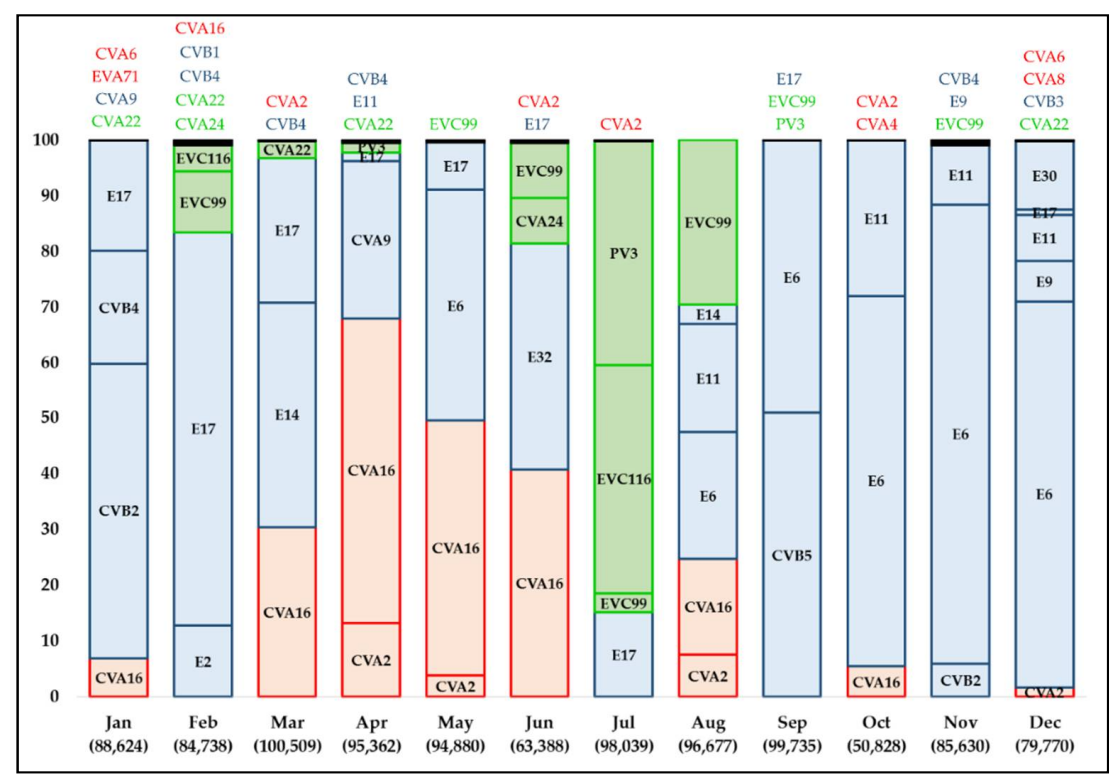

(a)

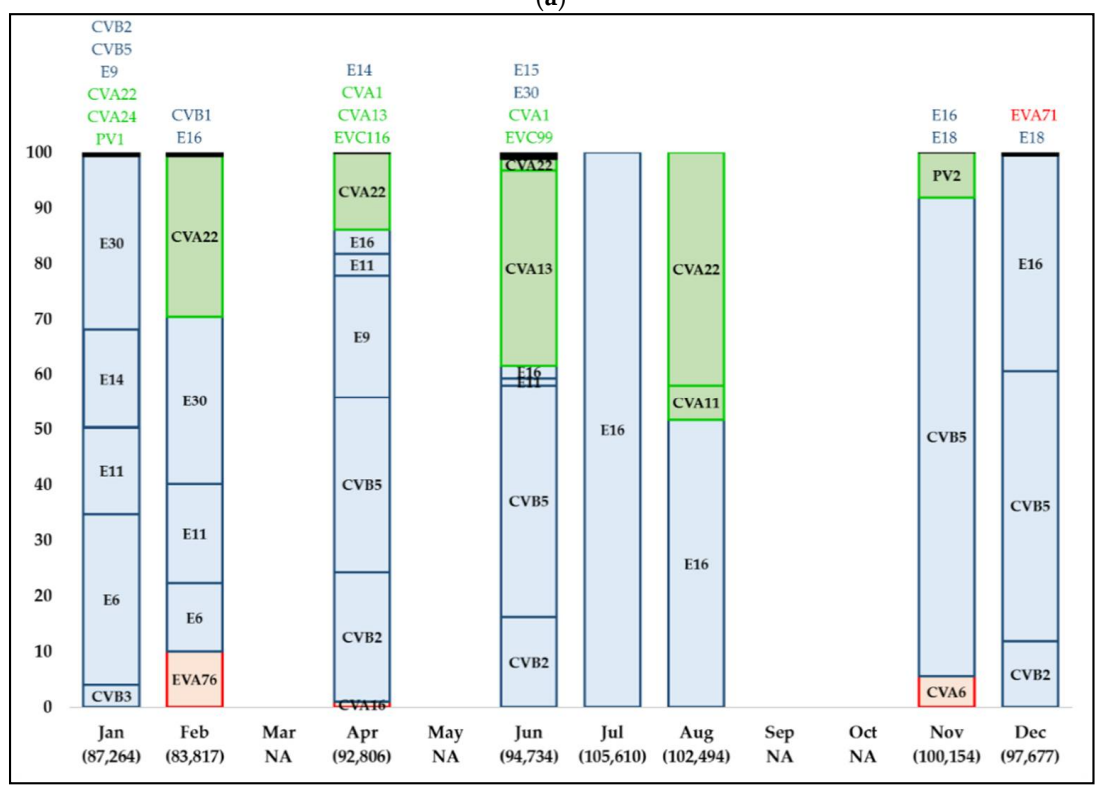

(b) 


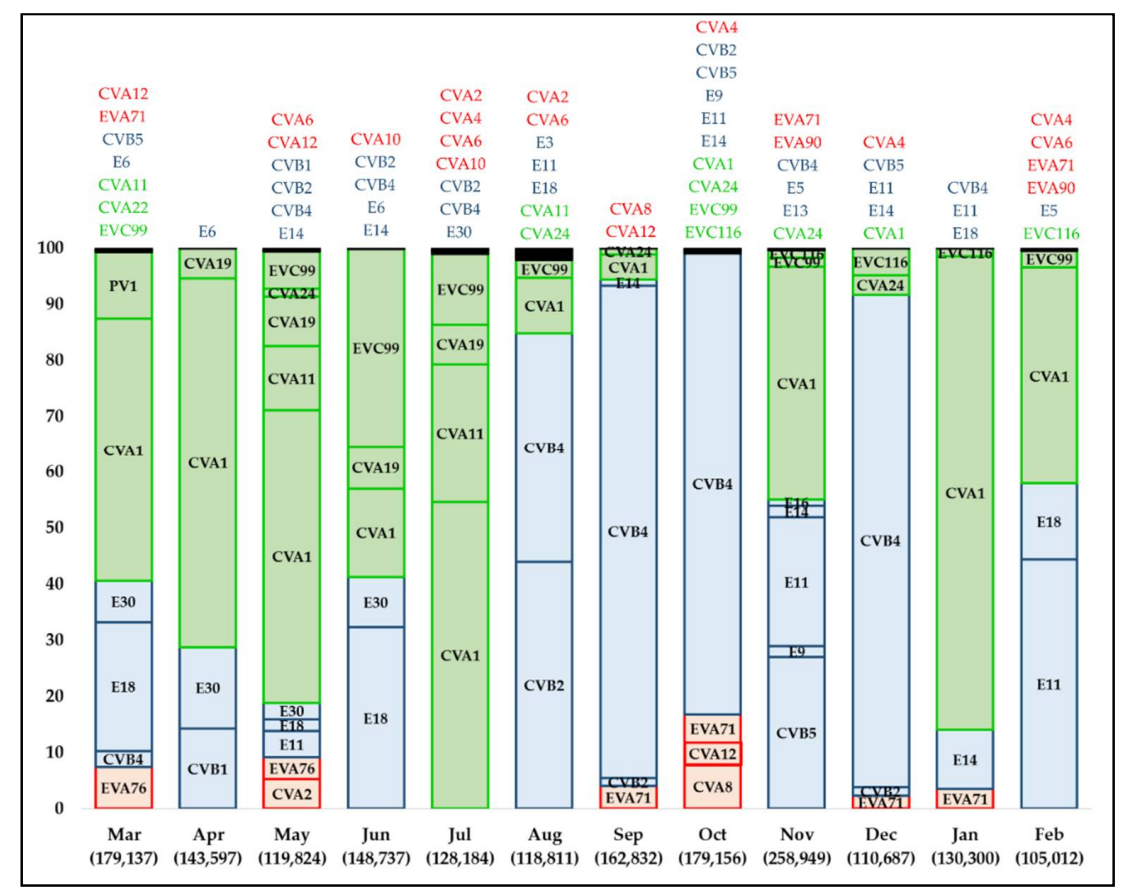

(c)

Figure 1. Abundance of contigs mapping to different Human Enteroviruses types/species in wastewater samples monthly collected in Córdoba City (Argentina) during 2011 (a), 2012 (b), and 20172018 (c). The bar-graphs show the relative abundance in percentage of contigs mapping to different Human Enteroviruses types for each sample. Types represented by less than $1 \%$ of the mapped contigs, abundances which are accumulated in a black portion, appear named and colored according the species at the top of each bar. Types belonging to species A are in red, to species B in blue, and to species C in green. Samples from March, May, September, and October 2012 were not assayed (NA) due to low volumes of available viral concentrates. The total number of contigs mapping to Human Enteroviruses is indicated between parentheses for each sample. CVA: coxsackievirus type A; CVB: coxsackievirus type B; E: echovirus; EVA: enterovirus type A; EVB: enterovirus type B; EVC: enterovirus type $\mathrm{C}$; PV: poliovirus.

Table 1. Variation in the abundance and efficiency of the typing process for contigs obtained by next-generation sequencing of Human Enteroviruses detected in wastewater samples.

\begin{tabular}{|c|c|c|c|c|c|c|}
\hline Sample & No. Contigs * & $\begin{array}{c}\text { No. Contigs } \\
\text { Represented by } \\
\text { Centroids }(n) \text { after } \\
\text { Clusterization, and } \\
\text { Quality Filtering }\end{array}$ & $\begin{array}{l}\text { No. Contigs } \\
\text { and Centroids } \\
\text { (n) Mapping to } \\
\text { CHED } \S\end{array}$ & $\begin{array}{l}\% \text { of Mapped } \\
\text { Contigs }\end{array}$ & $\begin{array}{l}\text { No. Types } \\
\text { Detected }\end{array}$ & $\begin{array}{c}\text { Normalization } \\
\text { (No. Types } \\
\text { Detected/100,000 } \\
\text { Contigs) }\end{array}$ \\
\hline Jan-11 & 100,139 & 88,677 (15) & $88,624(14)$ & 99.940 & 8 & 9 \\
\hline Feb-11 & 94,803 & $84,740(12)$ & $84,738(11)$ & 99.998 & 9 & 11 \\
\hline Mar-11 & 113,365 & $100,538(11)$ & $100,509(8)$ & 99.971 & 6 & 6 \\
\hline Apr-11 & 109,599 & $95,364(13)$ & $95,362(12)$ & 99.998 & 8 & 8 \\
\hline May-11 & 112,312 & $94,882(12)$ & $94,880(11)$ & 99.998 & 5 & 5 \\
\hline Jun-11 & 108,516 & $94,081(10)$ & $63,388(9)$ & 67.376 & 6 & 9 \\
\hline Jul-11 & 109,250 & $98,124(11)$ & $98,039(5)$ & 99.913 & 5 & 5 \\
\hline Aug-11 & 110,859 & $96,682(11)$ & $96,677(10)$ & 99.995 & 6 & 6 \\
\hline Sep-11 & 110,270 & $99,735(5)$ & $99,735(5)$ & 100 & 5 & 5 \\
\hline Oct-11 & 63,293 & $50,828(7)$ & $50,828(7)$ & 100 & 5 & 10 \\
\hline
\end{tabular}


Table 1. Cont.

\begin{tabular}{|c|c|c|c|c|c|c|}
\hline Sample & No. Contigs * & $\begin{array}{c}\text { No. Contigs } \\
\text { Represented by } \\
\text { Centroids }(n) \text { after } \\
\text { Clusterization, and } \\
\text { Quality Filtering }\end{array}$ & $\begin{array}{l}\text { No. Contigs } \\
\text { and Centroids } \\
\text { (n) Mapping to } \\
\text { CHED } \S\end{array}$ & $\begin{array}{l}\% \text { of Mapped } \\
\text { Contigs }\end{array}$ & $\begin{array}{l}\text { No. Types } \\
\text { Detected }\end{array}$ & $\begin{array}{c}\text { Normalization } \\
\text { (No. Types } \\
\text { Detected/100,000 } \\
\text { Contigs) }\end{array}$ \\
\hline Nov-11 & 110,198 & $85,630(11)$ & $85,630(11)$ & 100 & 6 & 7 \\
\hline Dec-11 & 101,611 & $79,770(14)$ & $79,770(14)$ & 100 & 10 & 13 \\
\hline Jan-12 & 103,427 & $87,296(18)$ & $87,264(17)$ & 99.963 & 11 & 13 \\
\hline Feb-12 & 100,802 & $83,832(13)$ & $83,817(11)$ & 99.982 & 7 & 8 \\
\hline Apr-12 & 107,125 & 92,808 (17) & $92,806(16)$ & 99.998 & 11 & 12 \\
\hline Jun-12 & 110,616 & $94,899(22)$ & $94,734(18)$ & 99.826 & 10 & 11 \\
\hline Jul-12 & 114,277 & $105,637(7)$ & $105,610(1)$ & 99.974 & 1 & 1 \\
\hline Aug-12 & 111,862 & $102,504(6)$ & $102,494(3)$ & 99.990 & 3 & 3 \\
\hline Nov-12 & 116,199 & $100,154(11)$ & $100,154(11)$ & 100 & 5 & 5 \\
\hline Dec-12 & 118,027 & 97,677 (12) & 97,677 (12) & 100 & 5 & 5 \\
\hline 2011-2012 & $\begin{array}{c}106,328 \\
( \pm 11,680)\end{array}$ & $\begin{array}{c}91,693(12) \\
\text { loss of } 14 \% \pm 4.1 \%\end{array}$ & 90,137 (10) & 98.346 & 7 & 8 \\
\hline Mar-17 & 204,856 & $179,282(37)$ & $179,137(35)$ & 99.919 & 13 & 7 \\
\hline Apr-17 & 205,429 & 187,007 (29) & $143,597(21)$ & 76.787 & 5 & 3 \\
\hline May-17 & 160,517 & $119,872(79)$ & $119,824(76)$ & 99.960 & 16 & 13 \\
\hline Jun-17 & 175,947 & $150,860(33)$ & $148,737(25)$ & 98.593 & 10 & 7 \\
\hline Jul-17 & 155,278 & $128,309(44)$ & $128,184(42)$ & 99.903 & 11 & 9 \\
\hline Aug-17 & 133,853 & 118,825 (25) & $118,811(22)$ & 99.988 & 11 & 9 \\
\hline Sep-17 & 179,041 & 165,549 (19) & $162,832(11)$ & 98.359 & 8 & 5 \\
\hline Oct-17 & 205,001 & $179,162(27)$ & $179,156(26)$ & 99.997 & 14 & 8 \\
\hline Nov-17 & 300,971 & $259,183(54)$ & $258,949(49)$ & 99.910 & 14 & 5 \\
\hline Dec-17 & 132,716 & $111,404(24)$ & $110,687(20)$ & 99.356 & 10 & 9 \\
\hline Jan-18 & 158,591 & $130,304(33)$ & $130,300(31)$ & 99.997 & 7 & 5 \\
\hline Feb-18 & 136,157 & $105,016(28)$ & $105,012(27)$ & 99.996 & 10 & 10 \\
\hline 2017-2018 & $\begin{array}{c}179,030 \\
( \pm 46,968)\end{array}$ & $\begin{array}{c}152,898(36) \\
\text { loss of } 15 \% \pm 5.3 \%\end{array}$ & $148,769(32)$ & 97.730 & 11 & 8 \\
\hline
\end{tabular}

* Resulting from raw paired reads merging. § CHED: Customized Human Enteroviruses Database (centroids were mapped against it for typing). Average values for 2011-2012 and 2017-2018 are in boldface.

\subsection{Human Enteroviruses Characterization}

In total, 41 different EVs types were detected: 10 types belonging to EV-A, 20 types to EV-B and 11 types to EV-C. Twenty-four out of 41 types were detected in both sampling periods (Figure 1; Figure S1).

According to the period of detection (2011-2012 and 2017-2018), several phylogenetic clusters were characterized for most of the different types (Figure S1). The majority of the phylogenetic clusters were detected exclusively during one of the sampling periods, but a lower number of them were composed by highly related centroid sequences detected at both periods (black squares of Figure S1).

The dynamics of EVs types within the three detected species was quite heterogeneous throughout the sampling period (Figure 1). In 2011-2012 period (Figure 1a,b), the predominant types were CVA2, CVA16 (EV-A), CVB4, CVB5, E6, E11, E14, E16, E17, E30 (EV-B), CVA22, EVC99 (EV-C). In the period considered between 2017 and 2018 (Figure 1c) the 
prominent ones were EVA71, CVA4, CVA6, CVA12 (EV-A), CVB2, CVB4, E11, E14, E18, E30 (EV-B), CVA1, CVA19, CVA24, EVC99 (EV-C).

\subsection{Nucleotide Identity}

Values of nucleotide identity among all pairs of centroid sequences for EVs types detected at both sampling periods (2011-2012 and 2017-2018) were in the range of 74.1$100 \%$, when all types were considered (Figure 2). The range of genetic identity values was similar for both periods, with few exceptions: wider ranges in 2017-2018 than in 2011-2012 were observed for EVA71, CVB4, E14, and E30; meanwhile the range of identity for CVB5 decreased in 2017-2018 compared with 2011-2012.

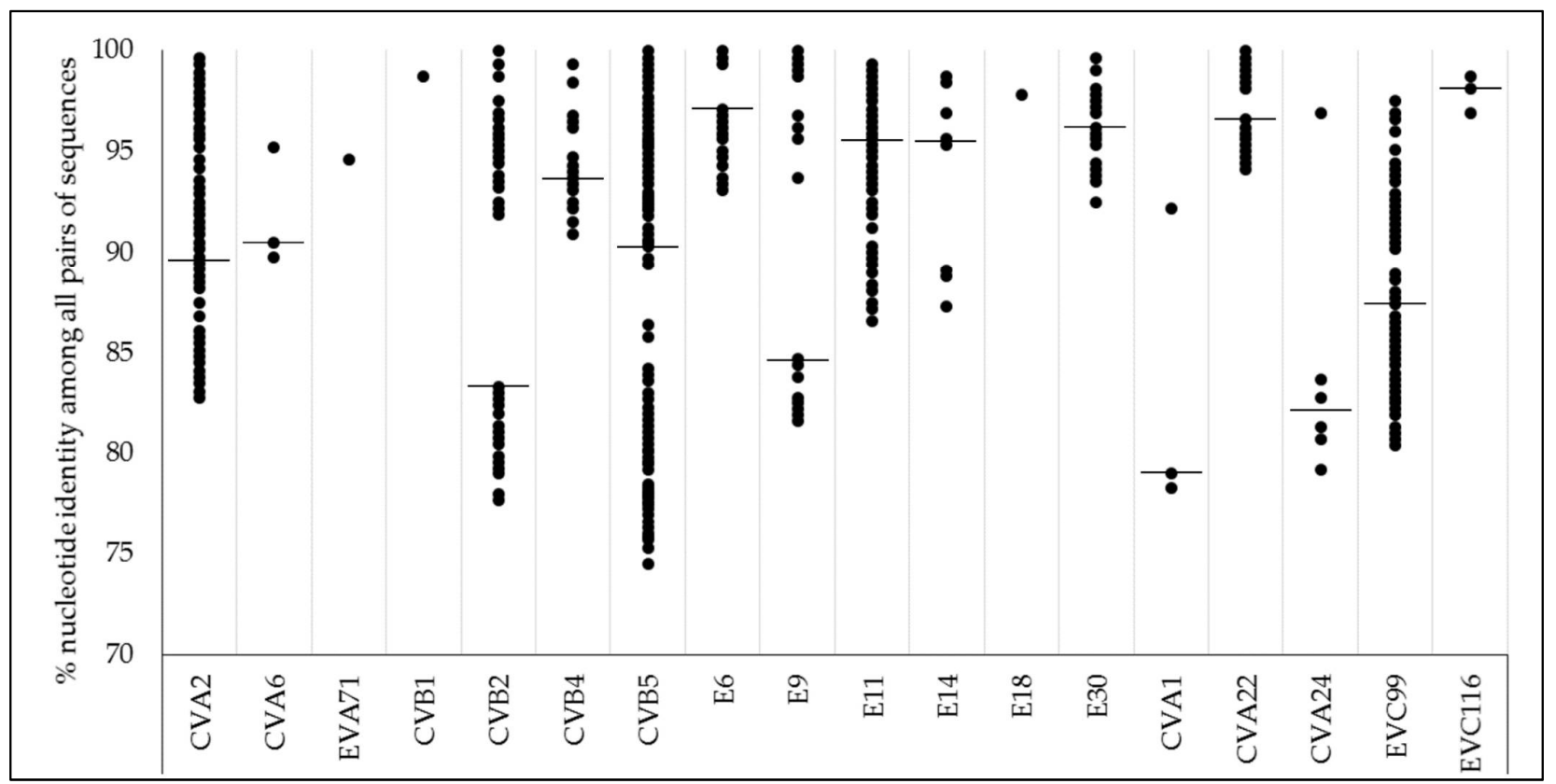

(a)

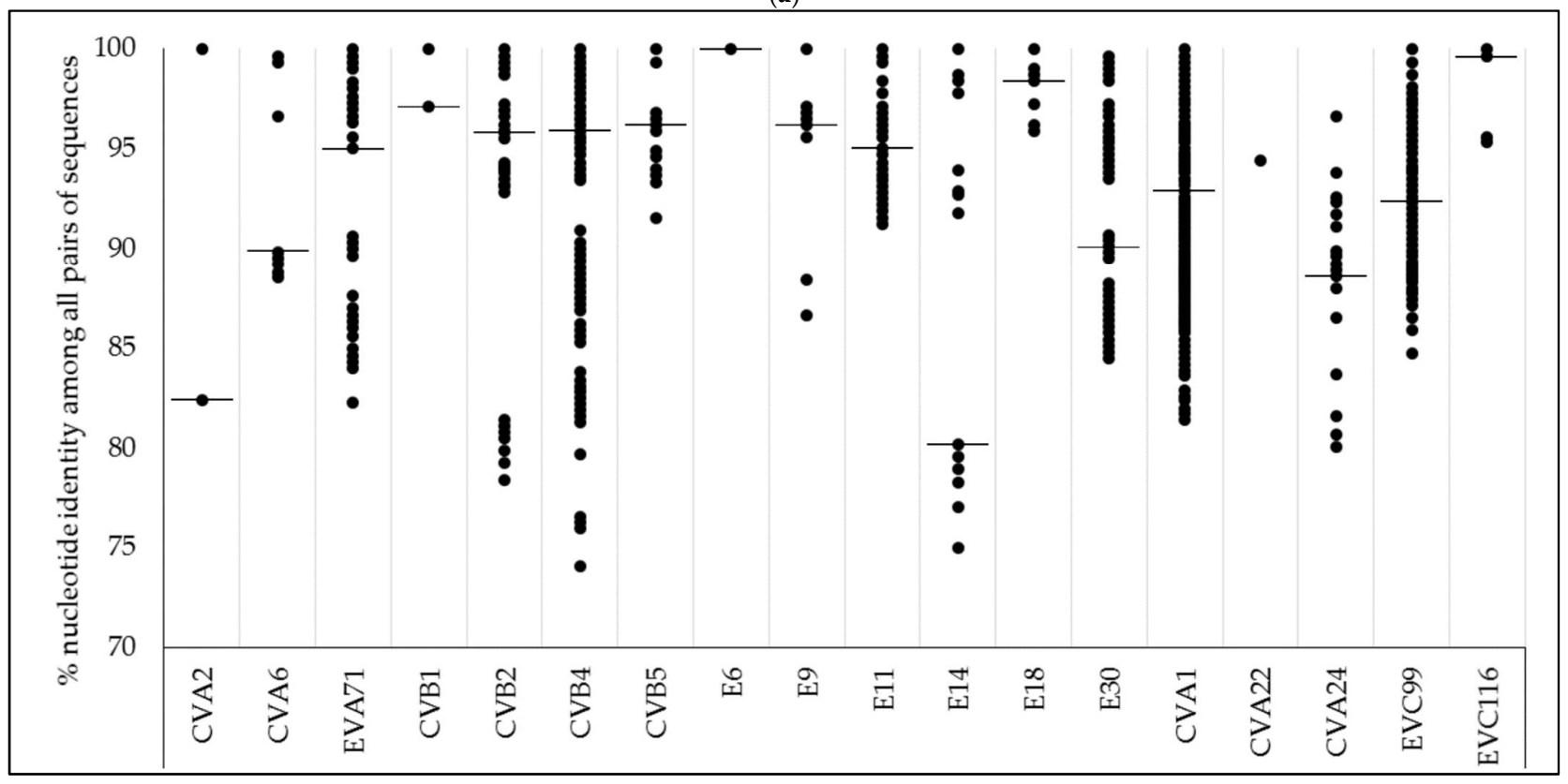

(b)

Figure 2. Nucleotide identity values over all the centroid sequences pairs for each Human Enterovirus type detected in wastewater samples from Córdoba City, Argentina in both periods (a) 2011-2012 and (b) 2017-2018. Horizontal bars indicate the median of nucleotide identity when more than a pair of centroid sequences was detected. 


\subsection{Backgrounds of Human Enteroviruses Detection in Argentina}

After the bibliographic and nucleotide database search, we noted that this study constitutes the first detection in Argentina for 40\% (15/38) of the non-polio EVs types detected here, mostly EV-A and EV-C types. Additionally, 17\% (4/23) of non-polio EV types (CVA2, EVA71, CVB1, and E11) with previous evidence of circulation in the country are types whose detection is barely mentioned in previous studies and are without a register in GenBank. The majority of EV-B types were previously detected in Argentina (17/19), although last reports were from 15 years ago (or more) for $\sim 50 \%$ of them (Table 2 ).

Table 2. Backgrounds of circulation in Argentina for Human Enteroviruses types detected in this study.

\begin{tabular}{|c|c|c|c|c|c|c|}
\hline Type & $\begin{array}{c}\text { More Recent } \\
\text { Reported Isolates }\end{array}$ & Year/Period & Location & Source & $\begin{array}{l}\text { Accession } \\
\text { Number }\end{array}$ & Reference \\
\hline CVA2 & Just mentioned $^{\mathrm{a}}$ & 1991-1998 & Unknown & $\mathrm{AM}$ & Unavailable & [23] \\
\hline CVA4 & Unknown & - & - & - & - & - \\
\hline CVA6 & $\begin{array}{l}\text { CVA6/BSAS/Arg001/ } \\
2018\end{array}$ & 2018 & Buenos Aires & HFMD & MK867799 & [39] \\
\hline CVA8 & Unknown & - & - & - & - & - \\
\hline CVA10 & Unknown & - & - & - & - & - \\
\hline CVA12 & Unknown & - & - & - & - & - \\
\hline CVA16 & 707F99 & Unknown & Unknown & Unknown & AF290092 & [11] \\
\hline EVA71 & Just mentioned $^{a}$ & 1991-1998 & Unknown & AM \& AFP & Unavailable & [23] \\
\hline EVA76 & Unknown & - & - & - & - & - \\
\hline EVA90 & Unknown & - & - & - & - & - \\
\hline CVA9 & Cba_Mar_2014_2 & 2014 & Córdoba & Wastewater & MK435332 & [21] \\
\hline CVB1 & Just mentioned $^{\mathrm{a}}$ & 1991-1998 & Unknown & AFP & Unavailable & [23] \\
\hline CVB2 & AR1530-3-03 & 2003 & Buenos Aires & $\begin{array}{l}\text { Neurological } \\
\text { disease }\end{array}$ & DQ282630 & [22] \\
\hline CVB3 & AR1450-49-02 & 2002 & Buenos Aires & $\begin{array}{l}\text { Neurological } \\
\text { disease }\end{array}$ & DQ246722 & [22] \\
\hline CVB4 & Cba_Mar_2010 & 2010 & Córdoba & Wastewater & MK435329 & {$[21]$} \\
\hline CVB5 & AR875-48-01 & 2001 & Buenos Aires & $\begin{array}{l}\text { Neurological } \\
\text { disease }\end{array}$ & DQ246729 & [22] \\
\hline E2 & AR1095-20-02 & 2002 & Buenos Aires & $\begin{array}{l}\text { Neurological } \\
\text { disease }\end{array}$ & DQ282634 & [22] \\
\hline E3 & Unknown & - & - & - & - & - \\
\hline E5 & AR1617-8-03 & 2003 & Buenos Aires & $\begin{array}{l}\text { Neurological } \\
\text { disease }\end{array}$ & DQ282627 & [22] \\
\hline E6 & Cba_Feb_2014_1 & 2014 & Córdoba & Wastewater & MK435318 & [21] \\
\hline E9 & AR1669_12_03 & 2003 & Buenos Aires & $\begin{array}{l}\text { Neurological } \\
\text { disease }\end{array}$ & DQ246752 & [22] \\
\hline E11 & Just mentioned $^{\mathrm{a}}$ & 2005-2006 & Buenos Aires & Surface water & Unavailable & [18] \\
\hline E13 & Cba_May_2013_1 & 2013 & Córdoba & Wastewater & MK435334 & {$[21]$} \\
\hline E14 & Cba_Set_2014 & 2014 & Córdoba & Wastewater & MK435346 & [21] \\
\hline E15 & Unknown & - & - & - & - & - \\
\hline E16 & Cba_Jun_2013 & 2013 & Córdoba & Wastewater & MK435326 & [21] \\
\hline E17 & 875NE99 & Unknown & Unknown & Unknown & AF290905 & [11] \\
\hline
\end{tabular}


Table 2. Cont.

\begin{tabular}{|c|c|c|c|c|c|c|}
\hline Type & $\begin{array}{c}\text { More Recent } \\
\text { Reported Isolates }\end{array}$ & Year/Period & Location & Source & $\begin{array}{l}\text { Accession } \\
\text { Number }\end{array}$ & Reference \\
\hline E18 & AR2109-44-03 & 2003 & Buenos Aires & $\begin{array}{l}\text { Neurological } \\
\text { disease }\end{array}$ & DQ246765 & [22] \\
\hline E30 & CHA468-ARG12 & 2012 & Chaco & $\mathrm{AM}$ & MK410196 & [13] \\
\hline E32 & Unknown & - & - & - & - & - \\
\hline CVA1 & Unknown & - & - & - & - & - \\
\hline CVA11 & Unknown & - & - & - & - & - \\
\hline CVA13 & $\begin{array}{c}\text { ARG98-10613/ARG98- } \\
10614\end{array}$ & 1998 & Unknown & Unknown & DQ995636 & [40] \\
\hline CVA19 & Unknown & - & - & - & - & - \\
\hline CVA22 & Unknown & - & - & - & - & - \\
\hline CVA24 & $\begin{array}{c}\text { Cba_Aug_2013/Cba_ } \\
\text { Aug_2014 }\end{array}$ & $2013 / 2014$ & Córdoba & Wastewater & MK435313 & [21] \\
\hline EVC99 & Unknown & - & - & - & - & - \\
\hline EVC116 & Unknown & - & - & - & - & - \\
\hline
\end{tabular}

${ }^{a}$ Human Enteroviruses (EVs) types mentioned as circulating in Argentina in an article, but without registry of nucleotide sequence in GenBank database. AM: Aseptic meningitis, AFP: acute flaccid paralysis, HFMD: Hand-foot-and-mouth disease.

\subsection{Link between Human Enteroviruses Detected in Wastewater and Clinical Isolates}

Nucleotide identity percentages of centroid sequences of echovirus 30 from this study and those available in GenBank obtained during the study of sporadic cases and outbreaks of AM accounted during 1998-2012 in different locations of Argentina [13] were compared (Table 3).

Table 3. Nucleotide identities among echovirus 30 strains detected in wastewater from Córdoba (in 2011, 2012, and 2017) and clinical isolates obtained from outbreaks and sporadic cases of aseptic meningitis accounted in Argentina between 1998 and 2012 reported by Lema et al., 2019 [13].

\begin{tabular}{|c|c|c|c|c|}
\hline & $\begin{array}{c}\text { Aseptic Meningitis } \\
\text { Outbreak Buenos } \\
\text { Aires a } \\
\text { (Oct 2011-Mar 2012) }\end{array}$ & $\begin{array}{l}\text { Two Aseptic } \\
\text { Meningitis Sporadic } \\
\text { Cases Córdoba } \\
\text { (Mar 2012) }\end{array}$ & $\begin{array}{l}\text { Aseptic Meningitis } \\
\text { Outbreak Chaco }^{\text {a }} \\
\text { (Feb 2012-Apr 2012) }\end{array}$ & $\begin{array}{c}\text { Other Echovirus } 30 \\
\text { Strains Detected in } \\
\text { 1998-2008 in } \\
\text { Argentina }\end{array}$ \\
\hline E30/COR/ARG/Dec_2011 & $95.9-99.3 \%$ & $99 \%$ & $97.8-99.3 \%$ & $87.9-92.2 \%$ \\
\hline E30/COR/ARG/Jan_2012 & $97.2-98.1 \%$ & $97.80 \%$ & $97.2-98.1 \%$ & $87.6-91.9 \%$ \\
\hline E30/COR/ARG/Feb_2012 & $97.5-98.4 \%$ & $98.10 \%$ & $97.5-98.4 \%$ & $87.3-92.2 \%$ \\
\hline E30/COR/ARG/Feb_2012 & 95.6-98.1\% & $97.80 \%$ & $97.2-98.4 \%$ & $87.3-91.9 \%$ \\
\hline E30/COR/ARG/Jun_2012 & $96.2-99.6 \%$ & $100 \%$ & $98.1-99.6 \%$ & $87.9-92.2 \%$ \\
\hline E30/COR/ARG/Mar_2017 & $86.4-87.3 \%$ & $87.30 \%$ & $86.1-87.3 \%$ & $87.9-92.2 \%$ \\
\hline E30/COR/ARG/Mar_2017 & $83.3-84.5 \%$ & $84.50 \%$ & $83.3-84.5 \%$ & $85.1-91.0 \%$ \\
\hline E30/COR/ARG/Mar_2017 & $84.2-85.8 \%$ & $85.10 \%$ & $84.5-85.8 \%$ & $87.6-91.9 \%$ \\
\hline E30/COR/ARG/Mar_2017 & $85.8-87.3 \%$ & $86.70 \%$ & $86.7-87.6 \%$ & $86.4-95.6 \%$ \\
\hline E30/COR/ARG/Mar_2017 & $84.5-86.7 \%$ & $86.10 \%$ & $85.4-86.7 \%$ & $86.1-92.5 \%$ \\
\hline E30/COR/ARG/Mar_2017 & $85.4-86.4 \%$ & $86.40 \%$ & $85.1-86.4 \%$ & $87.0-93.5 \%$ \\
\hline E30/COR/ARG/Apr_2017 & $85.4-87.0 \%$ & $86.40 \%$ & $86.4-87.3 \%$ & $87.3-95.3 \%$ \\
\hline E30/COR/ARG/May_2017 & $86.1-87.6 \%$ & $87.00 \%$ & $87.0-87.9 \%$ & $86.7-95.3 \%$ \\
\hline E30/COR/ARG/Jun_2017 & $85.8-87.3 \%$ & $86.70 \%$ & $86.7-87.6 \%$ & $87.0-95.6 \%$ \\
\hline E30/COR/ARG/Jul_2017 & $86.4-87.9 \%$ & $87.30 \%$ & $87.3-88.2 \%$ & $87.6-95.3 \%$ \\
\hline
\end{tabular}

a Buenos Aires and Chaco Provinces are located 435 and 534 miles, respectively, from Province of Córdoba. Percentages in boldface show a close genetic relationship among environmental and clinical isolates circulating in Argentina in 2011-2012. 
Echovirus 30 strains detected in wastewater in 2011 and 2012 were closely related with clinical isolates reported during outbreaks of AM accounted in Buenos Aires Province and Chaco Province in 2011 and 2012 (95.9-99.6\%), and with isolates reported from the study of two sporadic cases reported in 2012 in Córdoba (97.8-100\%). Instead, strains detected in wastewater in 2017 were more related with strains of clinical isolates from the period from 1998 to 2008 (85.1-95.6\%) than with those strains more recently detected from medical diagnosis of AM (83.3-88.2\%) in Argentina.

\section{Discussion}

We have studied the genetic diversity of EVs presented in wastewater from Córdoba, Argentina along two different sampling periods separated by a span of 5 years. Our analysis supports the circulation of 41 different EVs types during both periods, of which 38 of them are non-polio EVs.

The average numbers of types detected per 100,000 contigs were identical in the periods of 2011-2012 and 2017-2018 (Table 1), suggesting that differences initially observed in the detected number of types among periods were caused by sequencing depth, instead of an increased circulation of EV types during 2017-2018. To the best of our knowledge, this study represents the first detection in Argentina of 15 of these $38 \mathrm{EV}$ types, being in the majority first detections of EV-A (6/15) and EV-C (6/15) types in the country. Despite the fact that most of the EV-B types detected in this study had been previously reported in Argentina, half of them, the last record in the country was at least 15 years ago (Table 2). Therefore, the results of our work contribute to a better understanding and updating of the epidemiology and circulation dynamics of EV in this South American country.

This study documented for Córdoba, Argentina, the recent circulation of several well-known EVs types, to be linked to different diseases such as HFMD (coxsackievirus A6, A10, A16), AM (echovirus 6, 30, coxsackievirus A9, B4), AHC (coxsackievirus A24), AFP (echovirus 14 and enterovirus A71), among others [4]. Such diversity of EVs linked to different diseases deserves attention from the public health point of view since when it is interpreted together with the scarce data obtained from medical diagnoses, this suggests, in the worst possible scenario, an under-reporting of several diseases with important implications for the population's health. Additionally, environmental samples frequently contain viable EVs [29,41-43] which means that several of the detected EVs types represented certain risk of infection to those who were exposed to wastewater or to other polluted environmental matrices.

Different EVs types present different circulation and/or predominance patterns along time [44]. The five years gap between both assayed periods limited our study in addressing the epidemiologic patterns followed by each EV type since there was a loss of information during this impasse. Nonetheless, some results about EVs types' diversity along the sampling of this study deserve highlighting. First, 60\% (24/41) of the types detected in our study circulated both during 2011-2012 and during 2017-2018 (Figure S1), which could be either due to a prolonged circulation given by an endemic behavior, or resulted from recurrent entries into Córdoba that coincided with our sampling periods. Second, EVs types circulated under similar values of genetic diversity at each period (Figure 2). Nevertheless, there was a considerable expansion of the range of nucleotide identity towards lower values for EVA71 (EV-A), CVB4, E14, and E30 (EV-B) sequences in 2017-2018, which probably was a consequence of the introduction of phylogenetically distant strains at intra-type level after 2011-2012 (Figure S1). This highlights the dynamic circulation and indicates the need for future detailed inspection of clinical cases, potentially linked with these EV types in the community. Third, for some consecutive months (i.e., June-July 2012, NovemberDecember 2017) the diversity of EVs types abruptly changed (Figure 1). Other studies conducted in different parts of the world have also documented this complete (or almost complete) exchange of types from one month to another [27,45]. Diverse factors such as the differential seasonal fluctuations of types, immunity generation into population, occurrence of large outbreaks of different diseases, or the introduction of new viral variants, 
among many others, could act as driving forces of this pattern. Unfortunately, most of the environmental studies of EVs which used next-generation sequencing have been conducted during short sampling campaigns as in our case [26-28,45-47]. Long-term environmental surveillance projects could be useful to elucidate epidemiological patterns for EVs beyond the bounded subset of EVs commonly detected when clinical specimens obtained from AM or AFP cases are studied.

Another interesting aspect of our study that deserves attention is the variation in diversity of EV species along the sampling period (Figure 1). The most evident change happened in the abundance of EV-C types during 2017-2018 in comparison with 2011-2012. This change was mainly driven by the ignition of CVA1 during 2017-2018, although other types such as CVA11 or CVA19 also contributed to it. In line with the herein achieved results, recent studies have documented high percentages of detection of EV-C types in environmental samples from distant points of the world [26,48,49]. Besides many coxsackievirus-A types and some numbered enteroviruses, this species includes three poliovirus types [50]. During many years, global efforts against EVs transmission were focused on the eradication of wild polioviruses through vaccination [51]. Previous studies have speculated about a "vacated niche" once poliovirus is eradicated, and based on the close genetic relation with poliovirus and the plasticity of their genomes, coxsackievirusesA types from EV-C have been proposed as a potential successor of poliovirus in a poliovirusfree world [52]. Nevertheless, a recent study [53] did not find an increased circulation of EV-C types in a period characterized by less poliovirus circulation in a community, although this absence of detection of EV-C types could be the result of a bias introduced by the employed methods [54]. Therefore, the emergence of EV-C types as endemic viruses due to less poliovirus circulating in humans remains speculative. Nonetheless, the relevance of their silent spreading into a community should be the subject of future studies oriented towards a better understanding of the behavior of these rarely reported viruses from diagnoses [45,48,55].

Despite Argentina immunizing children with the live-attenuated Oral Poliovirus Vaccine (OPV) during the sampling periods of our study, we detected PV in 19\% (6/32) of the collected samples. This low frequency of detection could probably be due to an amount of OPV excretors lower than the amount of other non-polio enteroviruses excretors in the population, with the consequence of PV strains' dilution in the mixture of diverse EV types when wastewater samples are assayed with primers designed for broad target specificity. Nevertheless, other issues such as low catchment of immunized children shedding PV into the wastewater system, or different recovery efficiencies for different enteroviruses during the wastewater concentration procedure could be some of the factors affecting the PV detection rate in our study.

Unfortunately, there are few studies reporting EVs from medical diagnosis in Argentina $[12,13,17,22,23]$ and data encompassing our sampling are not enough to make a detailed comparison among clinical and environmental strains for the 41 types herein detected. Nevertheless, echovirus 30 has probably been the most extensively studied EV type in Argentina [11-13], and there are several nucleotide sequences publicly available. This allowed us to conduct a retrospective comparison of echovirus 30 strains detected in this study with isolates obtained during outbreaks and sporadic cases of AM accounted in Córdoba and in other provinces of Argentina [13]. This comparison evidenced a close phylogenetic relation among environmental strains detected in Córdoba in samples taken from 2011-2012, and clinical isolates both from Córdoba and other locations from Argentina reported during those same years. Interestingly, our results show that when sporadic cases of AM linked with echovirus 30 were reported in Córdoba (March 2012) the virus had been circulating in the wastewater of the city for at least three months prior (Table 3). Similarly, a previous study [56] reported the silent circulation of echovirus 30 in the environment before the onset of a large outbreak of AM accounted in 2009 in Finland. However, a study conducted in Russia [57], failed in associating clinical and environmental isolates of echovirus 30 in the same temporal and geographical scenario, reporting echovirus 30 
almost exclusively from medical diagnosis of AM. This emphasizes the use of highly sensitive and effective methods to unveil the complex diversity of EVs in environmental samples when wastewater-based epidemiology approaches are conducted. The lack of reports of AM linked to echovirus 30 in Argentina since 2012 made it impossible for us to compare the characterized environmental strains with contemporaneous clinical isolates. A link between environmental and clinical isolates of different EVs obtained in the same temporal and geographical range has been extensively documented [57-59]. Nevertheless, our study suggests that echovirus 30 strains detected in the environment of a specific location could predict future epidemics beyond local boundaries. This has a valuable application in a potential national environmental surveillance system based on sentinel points for anticipating the occurrence of outbreaks.

Despite the fact that our approach is an improvement compared to the classic diagnostic methods routinely used across laboratories [60], and the fact that it allowed the detection of up to 16 different EVs per sample; other similar approaches have shown a higher sensitivity [26,45]. Different issues such as the wastewater concentration method, the amount of template used in RNA extraction, RT-PCR methods, or some details regarding the sampling strategy or, indeed, epidemiological aspects could be affecting the number of types detected per sample among different studies. Future comparative studies are needed in order to know the advantages and disadvantages of each approach to evaluate their applicability in accomplishing different specific goals.

In summary, we implemented a wastewater-based epidemiology approach with nextgeneration sequencing of a viral gene amplified by PCR in order to depict the diversity of EVs circulating in Córdoba, Argentina. This leads to a better characterization of the presence of these viruses in the country, showing how useful this kind of approach iswhen continuously conducted from the wastewater of a community-to know in advance the circulation of EVs potentially hazardous for the public health.

Supplementary Materials: The following are available online at https://www.mdpi.com/1999-4 915/13/1/120/s1, Figure S1A-C: Maximum likelihood phylogenetic trees of Human Enterovirus species A (A), B (B), and C (C). Each tree was constructed with centroid sequences detected in wastewater samples from Córdoba City (Argentina) during this study and representative sequences of different Human Enteroviruses types reported elsewhere. Dotted lines projecting outward from branches represent centroid sequences. Colored circles and squares indicate the period(s) in which different phylogenetic clusters of this study were detected. aLRT-SH values at type-definition node levels were $>0.7$ for all types. The bar at the center of each phylogenetic tree denotes genetic distance. CVA: coxsackievirus type A; CVB: coxsackievirus type B; E: echovirus; EVA: enterovirus type A; EVB: enterovirus type B; EVC: enterovirus type C; PV: poliovirus. Table S1: Information about clinical isolates of echovirus 30 obtained from aseptic meningitis cases accounted in Argentina in 1998-2012 (reported by Lema et al. 2019 [13]), used in a comparison with echovirus 30 strains detected in wastewater by this study.

Author Contributions: Conceptualization, A.L. and R.C.; data curation, A.L. and D.M.; formal analysis, A.L. and D.M.; funding acquisition, S.N. and R.C.; investigation, A.L., D.M., G.M., and A.F.; methodology, A.L., D.M., M.V., and R.C.; project administration, R.C.; resources, N.R.-O., S.N., and R.C.; software, D.M.; supervision, R.C.; validation, A.L. and R.C.; visualization, A.L. and D.M.; writing—original draft, A.L.; writing—review and editing, A.L., D.M., G.M., A.F., N.R.-O., M.V., S.N., and R.C. All authors have read and agreed to the published version of the manuscript.

Funding: This research was funded by Programa Polos de Desarrollo Universitario from Comisión Coordinadora del Interior of the Universidad de la República, Uruguay, grant PDU2010, and by National Agency for Scientific and Technological Promotion, Argentina, ANPCyT-FONCyT-PICT 2016 grant 2165. Authors receive financial support from Sistema Nacional de Investigadores (SNI) of Agencia Nacional de Investigación e Innovación (ANII), Uruguay, and from Consejo Nacional de Investigaciones Científicas y Técnicas (CONICET), Argentina. A.L. received a PhD scholarship in 2016-2019 from Comisión Académica de Posgrado (CAP) and Programa de Desarrollo de las Ciencias Básicas (PEDECIBA) of Universidad de la República, Uruguay.

Institutional Review Board Statement: Not applicable. 
Informed Consent Statement: Not applicable.

Data Availability Statement: Sequencing data is openly available in Sequence Read Archive (SRA) repository under BioProject number PRJNA689577.

Acknowledgments: Authors thank Asociación de Universidades Grupo Montevideo (AUGM) for promoting scientific collaboration between their research groups.

Conflicts of Interest: The authors declare no conflict of interest. The funders had no role in the design of the study; in the collection, analyses, or interpretation of data; in the writing of the manuscript; or in the decision to publish the results.

\section{References}

1. Zell, R.; Delwart, E.; Gorbalenya, A.E.; Hovi, T.; King, A.M.Q.; Knowles, N.J.; Lindberg, A.M.; Pallansch, M.A.; Palmenberg, A.C.; Reuter, G.; et al. ICTV Virus Taxonomy Profile: Picornaviridae. J. Gen. Virol. 2017, 98, 2421-2422. [CrossRef]

2. Muehlenbachs, A.; Bhatnagar, J.; Zaki, S.R. Tissue tropism, pathology and pathogenesis of enterovirus infection. J. Pathol. 2014, 235, 217-228. [CrossRef] [PubMed]

3. Stalkup, J.R.; Chilukuri, S. Enterovirus infections: A review of clinical presentation, diagnosis, and treatment. Dermatol. Clin. 2002, 20, 217-223. [CrossRef]

4. Tapparel, C.; Siegrist, F.; Petty, T.J.; Kaiser, L. Picornavirus and enterovirus diversity with associated human diseases. Infect. Genet. Evol. 2013, 14, 282-293. [CrossRef] [PubMed]

5. De Crom, S.C.M.; Rossen, J.W.A.; Van Furth, A.M.; Obihara, C.C. Enterovirus and parechovirus infection in children: A brief overview. Eur. J. Nucl. Med. Mol. Imaging 2016, 175, 1023-1029. [CrossRef]

6. Centers for Disease Control and Prevention. National Center for Immunization and Respiratory Diseases (NCIRD), Division of Viral Diseases Non-Polio Enterovirus. Transmission. Available online: https:/ /www.cdc.gov/non-polio-enterovirus/about/ transmission.html (accessed on 30 March 2020).

7. Melnick, J.L.; Rennick, V. Infectivity liters of enterovirus as found in human stools. J. Med. Virol. 1980, 5, 205-220. [CrossRef]

8. Tao, Z.; Wang, Z.; Lin, X.; Wang, S.; Wang, H.; Yoshida, H.; Xu, A.; Song, Y. One-year Survey of human enteroviruses from sewage and the factors affecting virus adsorption to the suspended solids. Sci. Rep. 2016, 6, 31474. [CrossRef]

9. Benschop, K.S.M.; Van Der Avoort, H.G.; Jusic, E.; Vennema, H.; Van Binnendijk, R.; Duizer, E. Polio and Measles Down the Drain: Environmental Enterovirus Surveillance in the Netherlands, 2005 to 2015. Appl. Environ. Microbiol. 2017, 83, e00558-17. [CrossRef]

10. Lukashev, A.N.; Vakulenko, Y.A.; Turbabina, N.A.; Deviatkin, A.A.; Drexler, J.F. Molecular epidemiology and phylogenetics of human enteroviruses: Is there a forest behind the trees? Rev. Med. Virol. 2018, 28, e2002. [CrossRef]

11. Palacios, G.; Casas, I.; Cisterna, D.; Trallero, G.; Tenorio, A.; Freire, C. Molecular Epidemiology of Echovirus 30: Temporal Circulation and Prevalence of Single Lineages. J. Virol. 2002, 76, 4940-4949. [CrossRef]

12. Farías, A.; Cabrerizo, M.; Ré, V.; Glatstein, N.; Pisano, B.; Spinsanti, L.; Contigiani, M.S. Molecular identification of human enteroviruses in children with neurological infections from the central region of Argentina. Arch. Virol. 2010, 156, 129-133. [CrossRef] [PubMed]

13. Lema, C.; Torres, C.; Van Der Sanden, S.; Cisterna, D.M.; Freire, M.C.; Gomez, R.M. Global phylodynamics of Echovirus 30 revealed differential behavior among viral lineages. Virology 2019, 531, 79-92. [CrossRef] [PubMed]

14. Freire, M.C.; Cisterna, D.M.; Rivero, K.; Palacios, G.; Casas, I.; Tenorio, A.; Gomez, J.A. Análisis de un brote de meningitis viral en la provincia de Tucumán, Argentina. Rev. Panam. Salud. Pública. 2003, 13, 246-251. [CrossRef] [PubMed]

15. Grenón, S.L.; Robledo, M.L.; von Specht, M.H.; Cisterna, D.M.; Lema, C.L.; Freire, M.C. Brote epidémico de meningitis viral causado por echovirus tipo 4 en la provincia de Misiones. Rev. Argent. Microbiol. 2008, 40, 41-46.

16. Ruggieri, V.; Paz, M.I.; Peretti, M.G.; Rugilo, C.; Bologna, R.; Freire, C.; Vergel, S.; Savransky, A. Enterovirus D68 infection in a cluster of children with acute flaccid myelitis, Buenos Aires, Argentina, 2016. Eur. J. Paediatr. Neurol. 2017, 21, 884-890. [CrossRef]

17. Cisterna, D.M.; Lema, C.L.; Martinez, L.M.; Verón, E.; Contarino, L.P.; Acosta, D.; Freire, M.C. Atypical hand, foot, and mouth disease caused by Coxsackievirus A6 in Argentina in 2015. Rev. Argent. Microbiol. 2019, 51, 140-143. [CrossRef]

18. Cisterna, D.; Lema, C.; Riviello López, G.; Freyre, L.; Martínez, L.; Torres, C.; Mbayed, V.; Freire, M.C. Detección y Caracterización de Enterovirus y Hepatitis A en el Riachuelo y Río de la Plata. In Libro de Resúmenes del IX Congreso Argentino de Virología 2008. Buenos Aires, Argentina, 2008; Revista Argentina de Microbiología: Buenos Aires, Argentina, 2008; abstract number 69-22999; pp. 49-50.

19. Mueller, J.E.; Bessaud, M.; Huang, S.; Martinez, L.C.; Barril, P.A.; Morel, V.; Balanant, J.; Bocacao, J.; Hewitt, J.; Gessner, B.D.; et al. Environmental Poliovirus Surveillance during Oral Poliovirus Vaccine and Inactivated Poliovirus Vaccine Use in Córdoba Province, Argentina. Appl. Environ. Microbiol. 2009, 75, 1395-1401. [CrossRef]

20. Farías, A.A.; Mojsiejczuk, L.; Pisano, M.B.; Flores, F.S.; Aguilar, J.J.; Jean, A.N.; Yanes, L.A.; Masachessi, G.; Prez, V.E.; Isa, M.B.; et al. Environmental Surveillance of Enteroviruses in Central Argentina: First Detection and Evolutionary Analyses of E14. Food Environ. Virol. 2018, 10, 121-126. [CrossRef] 
21. Farías, A.A.; Mojsiejczuk, L.; Flores, F.S.; Aguilar, J.J.; Prez, V.E.; Masachessi, G.; Nates, S.V. Environmental Surveillance of Human Enteroviruses in Córdoba City, Argentina: Prevalence and Detection of Serotypes from 2009 to 2014. Food Environ. Virol. 2019, 11, 198-203. [CrossRef]

22. Mistchenko, A.S.; Viegas, M.; Latta, M.P.; Barrero, P.R. Molecular and epidemiologic analysis of enterovirus B neurological infection in Argentine children. J. Clin. Virol. 2006, 37, 293-299. [CrossRef]

23. Cisterna, D.M.; Palacios, G.; Rivero, K.; Girard, D.; Lema, C.; Freire, M.C. Epidemiology of enterovirus associated with neurologic diseases [in Spanish]. Medicina (B Aires) 2007, 67, 113-119. [PubMed]

24. Wang, H.; Tao, Z.; Li, Y.; Lin, X.; Yoshida, H.; Song, L.; Zhang, Y.; Wang, S.; Cui, N.; Xu, W.; et al. Environmental Surveillance of Human Enteroviruses in Shandong Province, China, 2008 to 2012: Serotypes, Temporal Fluctuation, and Molecular Epidemiology. Appl. Environ. Microbiol. 2014, 80, 4683-4691. [CrossRef] [PubMed]

25. Joffret, M.-L.; Polston, P.M.; Razafindratsimandresy, R.; Bessaud, M.; Heraud, J.-M.; Delpeyroux, F. Whole Genome Sequencing of Enteroviruses Species A to D by High-Throughput Sequencing: Application for Viral Mixtures. Front. Microbiol. 2018, 9, 2339. [CrossRef] [PubMed]

26. Majumdar, M.; Sharif, S.; Klapsa, D.; Wilton, T.; Alam, M.M.; Fernandez-Garcia, M.D.; Rehman, L.; Mujtaba, G.; McAllister, G.; Harvala, H.; et al. Environmental Surveillance Reveals Complex Enterovirus Circulation Patterns in Human Populations. Open Forum Infect. Dis. 2018, 5, ofy250. [CrossRef] [PubMed]

27. Bisseux, M.; Debroas, D.; Mirand, A.; Archimbaud, C.; Peigue-Lafeuille, H.; Bailly, J.-L.; Henquell, C.; Didier, D.; Audrey, M.; Christine, A.; et al. Monitoring of enterovirus diversity in wastewater by ultra-deep sequencing: An effective complementary tool for clinical enterovirus surveillance. Water Res. 2020, 169, 115246. [CrossRef] [PubMed]

28. Martínez-Puchol, S.; Rusiñol, M.; Fernández-Cassi, X.; Timoneda, N.; Itarte, M.; Andrés, C.; Antón, A.; Abril, J.F.; Girones, R.; Bofill-Mas, S. Characterisation of the sewage virome: Comparison of NGS tools and occurrence of significant pathogens. Sci. Total. Environ. 2020, 713, 136604. [CrossRef]

29. Masachessi, G.; Pisano, M.B.; Prez, V.E.; Martínez, L.C.; Michelena, J.F.; Martínez-Wassaf, M.; Giordano, M.O.; Isa, M.B.; Pavan, J.V.; Welter, A.; et al. Enteric Viruses in Surface Waters from Argentina: Molecular and Viable-Virus Detection. Appl. Environ. Microbiol. 2017, 84, e02327-17. [CrossRef]

30. Instituto Nacional de Estadística y Censos de la República Argentina. Censo Nacional de Población, Hogares y Viviendas. Available online: https:/ / www.indec.gob.ar/indec/web/Nivel4-Tema-2-41-135 (accessed on 13 January 2021).

31. Nix, W.A.; Oberste, M.S.; Pallansch, M.A. Sensitive, Seminested PCR Amplification of VP1 Sequences for Direct Identification of All Enterovirus Serotypes from Original Clinical Specimens. J. Clin. Microbiol. 2006, 44, 2698-2704. [CrossRef]

32. Illumina support web-site. Available online: https://support.illumina.com/documents/documentation/chemistry documentation/16s/16s-metagenomic-library-prep-guide-15044223-b.pdf (accessed on 14 December 2020).

33. Rognes, T.; Flouri, T.; Nichols, B.; Quince, C.; Mahé, F. VSEARCH: A versatile open source tool for metagenomics. PeerJ. 2016, 4, e2584. [CrossRef]

34. Li, W.; Godzik, A. Cd-hit: A fast program for clustering and comparing large sets of protein or nucleotide sequences. Bioinformatics 2006, 22, 1658-1659. [CrossRef]

35. Price, M.N.; Dehal, P.S.; Arkin, A.P. FastTree 2-Approximately Maximum-Likelihood Trees for Large Alignments. PLoS ONE 2010, 5, e9490. [CrossRef] [PubMed]

36. Shimodaira, H.; Hasegawa, M. CONSEL: For assessing the confidence of phylogenetic tree selection. Bioinformatics 2001, 17, 1246-1247. [CrossRef] [PubMed]

37. Anisimova, M.; Gascuel, O. Approximate Likelihood-Ratio Test for Branches: A Fast, Accurate, and Powerful Alternative. Syst. Biol. 2006, 55, 539-552. [CrossRef]

38. Hall, T.A. BioEdit: A user-friendly biological sequences alignment editor and analysis program for Windows 95/98/NT. Nucl. Acids. Symp. Ser. 1999, 41, 95-98.

39. Sapia, E.Y.; Maroni, C.; Groisman, C.; Kromer, H.; Rojo, G.L.; Dastugue, M.; Valinotto, L. Genotipificación del virus de la enfermedad mano-pie-boca atípica en un hospital pediátrico de la Ciudad de Buenos Aires, Argentina. Arch. Argent. Pediatr. 2020, 118, e199-e203. [CrossRef] [PubMed]

40. Brown, B.A.; Maher, K.; Flemister, M.R.; Naraghi-Arani, P.; Uddin, M.; Oberste, M.S.; Pallansch, M.A. Resolving ambiguities in genetic typing of human enterovirus species $C$ clinical isolates and identification of enterovirus 96,99 and 102. J. Gen. Virol. 2009, 90, 1713-1723. [CrossRef]

41. Adeniji, J.A.; Faleye, T.O.C. Isolation and Identification of Enteroviruses from Sewage and Sewage-Contaminated Water in Lagos, Nigeria. Food Environ. Virol. 2014, 6, 75-86. [CrossRef]

42. Wieczorek, M.; Ciąćka, A.; Witek, A.; Kuryk, Ł.; Żuk-Wasek, A. Environmental Surveillance of Non-polio Enteroviruses in Poland, 2011. Food Environ. Virol. 2015, 7, 224-231. [CrossRef]

43. Prez, V.; Martínez, L.; Victoria, M.; Giordano, M.; Masachessi, G.; Ré, V.; Pavan, J.; Colina, R.; Barril, P.; Nates, S. Tracking enteric viruses in green vegetables from central Argentina: Potential association with viral contamination of irrigation waters. Sci. Total. Environ. 2018, 665-671. [CrossRef]

44. Pons-Salort, M.; Oberste, M.S.; Pallansch, M.A.; Abedi, G.R.; Takahashi, S.; Grenfell, B.T.; Grassly, N.C. The seasonality of nonpolio enteroviruses in the United States: Patterns and drivers. Proc. Natl. Acad. Sci. USA 2018, 115, 3078-3083. [CrossRef] 
45. Brinkman, N.E.; Fout, G.S.; Keely, S.P. Retrospective Surveillance of Wastewater To Examine Seasonal Dynamics of Enterovirus Infections. mSphere 2017, 2, e00099-17. [CrossRef] [PubMed]

46. Baicus, A.; Joffret, M.-L.; Bessaud, M.; Delpeyroux, F.; Oprisan, G. Reinforced poliovirus and enterovirus surveillance in Romania, 2015-2016. Arch. Virol. 2020, 165, 1-6. [CrossRef] [PubMed]

47. Tao, Z.; Chen, P.; Cui, N.; Lin, X.; Ji, F.; Liu, Y.; Xiong, P.; Zhang, L.; Xu, Q.; Song, Y.; et al. Detection of enteroviruses in urban sewage by next generation sequencing and its application in environmental surveillance. Sci. Total. Environ. 2020, 728, 138818. [CrossRef] [PubMed]

48. Harvala, H.; Calvert, J.; Van Nguyen, D.; Clasper, L.; Gadsby, N.; Molyneaux, P.; Templeton, K.; Leitch, C.M.; Simmonds, P. Comparison of diagnostic clinical samples and environmental sampling for enterovirus and parechovirus surveillance in Scotland, 2010 to 2012. Eurosurveillance 2014, 19, 20772. [CrossRef] [PubMed]

49. Ndiaye, A.K.; Mbathio, P.A.; Diop, P.A.M. Environmental surveillance of poliovirus and non-polio enterovirus in urban sewage in Dakar, Senegal (2007-2013). Pan Afr. Med. J. 2014, 19, 243. [CrossRef]

50. Brown, B.; Oberste, M.S.; Maher, K.; Pallansch, M.A. Complete Genomic Sequencing Shows that Polioviruses and Members of Human Enterovirus Species C Are Closely Related in the Noncapsid Coding Region. J. Virol. 2003, 77, 8973-8984. [CrossRef]

51. Kew, O.; Pallansch, M. Breaking the Last Chains of Poliovirus Transmission: Progress and Challenges in Global Polio Eradication. Annu. Rev. Virol. 2018, 5, 427-451. [CrossRef]

52. Jiang, P.; Faase, J.A.J.; Toyoda, H.; Paul, A.; Wimmer, E.; Gorbalenya, A.E. Evidence for emergence of diverse polioviruses from C-cluster coxsackie A viruses and implications for global poliovirus eradication. Proc. Natl. Acad. Sci. USA 2007, 104, 9457-9462. [CrossRef]

53. Zhao, C.; Lin, X.; Ji, F.; Xiong, P.; Liu, Y.; Wang, S.; Chen, P.; Xu, Q.; Zhang, L.; Tao, Z.; et al. Prevalence and Bayesian Phylogenetics of Enteroviruses Derived From Environmental Surveillance Around Polio Vaccine Switch Period in Shandong Province, China. Food Environ. Virol. 2020, 12, 321-332. [CrossRef]

54. Faleye, T.O.C.; Adeniji, J.A. Enterovirus Species B Bias of RD Cell Line and Its Influence on Enterovirus Diversity Landscape. Food Environ. Virol. 2015, 7, 390-402. [CrossRef]

55. Bubba, L.; Broberg, E.K.; Jasir, A.; Simmonds, P.; Harvala, H.; Redlberger-Fritz, M.; Nikolaeva-Glomb, L.; Havlíčková, M.; Rainetova, P.; Fischer, T.K.; et al. Circulation of non-polio enteroviruses in 24 EU and EEA countries between 2015 and 2017 : A retrospective surveillance study. Lancet Infect. Dis. 2020, 20, 350-361. [CrossRef]

56. Savolainen-Kopra, C.; Paananen, A.; Blomqvist, S.; Klemola, P.; Simonen, M.-L.; Lappalainen, M.; Vuorinen, T.; Kuusi, M.; Lemey, P.; Roivainen, M. A large Finnish echovirus 30 outbreak was preceded by silent circulation of the same genotype. Virus Genes 2010, 42, 28-36. [CrossRef] [PubMed]

57. Ivanova, O.E.; Yarmolskaya, M.S.; Eremeeva, T.P.; Babkina, G.M.; Baikova, O.Y.; Akhmadishina, L.V.; Krasota, A.Y.; Kozlovskaya, L.I.; Lukashev, A.N. Environmental Surveillance for Poliovirus and Other Enteroviruses: Long-Term Experience in Moscow, Russian Federation, 2004-2017. Viruses 2019, 11, 424. [CrossRef] [PubMed]

58. Sedmak, G.; Bina, D.; Macdonald, J. Assessment of an Enterovirus Sewage Surveillance System by Comparison of Clinical Isolates with Sewage Isolates from Milwaukee, Wisconsin, Collected August 1994 to December 2002. Appl. Environ. Microbiol. 2003, 69, 7181-7187. [CrossRef] [PubMed]

59. Tao, Z.; Song, Y.; Wang, H.; Zhang, Y.; Yoshida, H.; Ji, S.; Xu, A.; Song, L.; Liu, Y.; Cui, N.; et al. Intercity Spread of Echovirus 6 in Shandong Province, China: Application of Environmental Surveillance in Tracing Circulating Enteroviruses. Appl. Environ. Microbiol. 2012, 78, 6946-6953. [CrossRef]

60. Harvala, H.; Broberg, E.; Benschop, K.; Berginc, N.; Ladhani, S.N.; Susi, P.; Christiansen, C.; McKenna, J.; Allen, D.; Makiello, P.; et al. Recommendations for enterovirus diagnostics and characterisation within and beyond Europe. J. Clin. Virol. 2018, 101, 11-17. [CrossRef] [PubMed] 